\title{
Neighbourhood cohesion and territorial cohesion: in search for conceptual integrity
}

\author{
Lukasz Damurski $\mathbb{D}$
}

Accepted: 27 September 2021 / Published online: 8 October 2021

(C) The Author(s) 2021

\begin{abstract}
Neighbourhood cohesion is a concept describing the residents' sense of community, engagement in acts of neighbouring, and attractiveness of living in the neighbourhood. Since 2000's the term 'cohesion' has also been used in geography and in spatial policy to represent the distribution of functions and opportunities in space. The two approaches seem be complementary, but they lack consistency and appropriate conceptual framework. This paper aims at developing an integrated methodological framework which will include both social and spatial aspects of cohesion at the local level. Its empirical content refers to studies conducted in 2017-2019 in five locations in Poland. Three methods of spatial analysis are presented depicting various aspects of territorial cohesion of a neighbourhood: functional balance, accessibility of facilities and match between supply and demand. Such approach enables effective measurement and comparison of neighbourhoods representing various settlement types. The results show that the highest levels of cohesion were obtained for large cities where the density of amenities is the highest, and the lowest levels were noted in suburban settlements which confirms their malfunctioning character. The paper concludes with a critical revision of the concept of
\end{abstract}

Ł. Damurski $(\bowtie)$

Faculty of Architecture, Wrocław University of Science and Technology, Poland; ul. Bolesława Prusa 53/55,

50-317 Wrocław, Poland

e-mail: lukasz.damurski@pwr.edu.pl neighbourhood cohesion which can serve as a guideline for local urban policy.

Keywords Neighbourhood cohesion - Territorial cohesion - Accessibility $\cdot$ Services provision - Local service centre

\section{Introduction}

Cohesion as a fundamental property of all living systems has been a research subject in various disciplines including psychology, sociology, anthropology, and biology since mid-twentieth century (Buckner, 1988). In 1980's it was successfully applied to local communities under the label of neighbourhood cohesion. According to this concept, a neighbourhood high in cohesion is an area where residents experience a strong sense of community, engage in frequent acts of neighbouring, and are highly attracted to live in and remain residents of the neighbourhood.

Since 2000's the term 'cohesion' has gained more and more attention among researchers in geography and in spatial policy (Faludi, 2007). Within this approach high level of territorial cohesion means an optimized and fair distribution of functions and opportunities in space. This understanding of cohesion has been used in the European Union as a basis for various policy measures, referred mostly to the 
national and regional levels. However, it remains a big challenge at the neighbourhood scale where quantitative parameters lack their explanatory power and need to be complemented by qualitative measures (Damurski et al., 2020a).

Hence the original concept of neighbourhood cohesion is missing the spatial dimension whereas the current territorial cohesion policies are missing appropriate measures for implementation at the local level. The paper starts the discussion on the construct of neighbourhood cohesion in the perspective of territorial approach to development. Its aim is to develop an integrated methodological framework which will include both social and spatial aspects of cohesion at the local level. The core research questions are:

(Q1) What are the relations between the concepts of territorial cohesion and neighbourhood cohesion?

(Q2) How can neighbourhood cohesion be measured taking territorial perspective?

These questions are be answered firstly through building an adequate, interdisciplinary conceptual framework and outlining the main meanings of the term 'neighbourhood cohesion' and 'territorial cohesion'. This section is followed by a thorough description of the methodological approach for empirical research, i.e. sample selection, social survey rules, geocoding and accessibility analysis. Then several examples of analyses conducted in five neighbourhoods in Poland are presented, including provision of services, accessibility of essential functions and match of demand and supply. In the conclusions the addedvalue of the proposed approach is discussed and a revised concept of neighbourhood cohesion is presented.

\section{Neighbourhood cohesion versus territorial cohesion}

Neighbourhood cohesion: origins

and measurement

The original concept of neighbourhood cohesion was an amalgamation of several approaches within social and psychological sciences. The term was developed by Buckner (1988) as a synthesis of psychological sense of community (PSOC), attraction-to-neighbourhood and social interaction within a neighbourhood. It assumed that residents living within a neighbourhood have a certain degree of cohesion. Operationalization of the concept included measuring three dimensions: PSOC; place attachment; and neighbourliness or social interaction. PSOC is defined as the perception of similarity to others (Colombo et al., 2001). Place attachment is an emotional bond with a place that is manifested through affective, cognitive, and behavioural psychological processes (Scannell \& Gifford, 2010). Social interaction is defined as people's networking within a neighbourhood that includes activities such as asking for help and informal visiting (Talen, 2000). As a result, a Neighbourhood Cohesion Index was calculated for these three dimensions (Youssef, 2015).

For An and Western (2019) neighborhood cohesion emphasizes the role played by both family and neighborhood environment on children's education. It is a set of relationships that exist among parents in the community, including helping each other in an emergency, watching the neighbours' children, counting on neighborhood residents, trusting each other and having safe places for their children in the neighborhood (An \& Western 2019). Similar approach has been presented by Zhu et al. (2014) who measured neighbourhood cohesion using a 5-point Likert scale by asking the respondents how much he/she agreed or disagreed with relevant statements, such as "neighbors can be counted to help in case of need" (Zhu et al., 2014).

Buckner's (1988) instrument for measuring neighbourhood cohesion has proven to be robust in bringing out differences between neighbourhoods and assessing their overall level of cohesion. The differences were connected with structural configuration (e.g. internal street pattern), and the location of focal points within a neighbourhood. Those spatial (or more precisely: morphological) features of a neighbourhood were not quantified in the Buckner's method however, being merely a descriptive (non-measurable) reference for comparative socio-psychological analysis.

Taking into account those deliberations in this paper a simplified definition of "neighbourhood cohesion' has been adopted, going back to the sociopsychological roots of the term: it means 
embeddedness of residents into particular space and positive (functional) social ties in the community.

Territorial cohesion: core interpretations of the concept

Territorial cohesion plays a crucial role in the European Union for conducting comparative research and building various development strategies. Faludi (2007) argues that the logic of territorial cohesion can be found in the Third Cohesion Report (European Commission, 2004), which stated that people should not be disadvantaged by wherever they happen to live or work in the EU. Territorial cohesion is thus about a just distribution of opportunities in space, seen as a precondition to achieve growth, competitiveness, employment and sustainable development (Nosek, 2017; Territorial Agenda, 2020).

One important strand of territorial cohesion is citizen access to public infrastructure and services. What can be expected, accessibility problems arise in areas where geographical isolation or lower population density makes provision less profitable. However, even where supply networks are built and problems of accessibility reduced, affordability issues may occur as market-oriented provision means that citizens bear the extra costs (Clifton et al., 2016). Therefore the implementation of cohesion policy focuses on supporting both growth poles and regions lagging behind.

Territorial cohesion may be also viewed as a feature (or a set of features) of a particular area. Each territory is characterised by higher or lower level of cohesion. A strong methodological modus procedendi for operationalizing territorial cohesion has been proposed by ESPON (2012) and Dao et al. (2017). In line with this approach 32 main indicators of territorial cohesion within 6 territorial priorities were generated and tested. Not all of them can be directly applied at the local scale. Some can be considered in wider contexts only (e.g. intramural expenditures on $\mathrm{R} \& \mathrm{D}$, accessibility potential by air, biodiversity, polycentricity), and some are too general to give representative results for urban neighbourhoods (e.g. old age dependency ratio). Hence the ESPON indicators form a kind of reference point for this research but cannot be implemented as-they-are into empirical neighbourhood studies (cf. Damurski et al., 2020a who tried to revise and adopt the measures to local level).
Following the principles of territorial cohesion, particular sectoral policies are implemented, such as the recent Interreg 2014-2020. The programme promoted an integrated, harmonious economic, social and territorial development through a budget of EUR 10.1 billion invested in over 100 cooperation actions between territorial, social and economic partners (Interreg website, 2021).

Bearing in mind those nuances in understanding 'territorial cohesion' in this paper the term has been defined as access to essential services and facilities for citizens in the environments where they live. On the local level it is strictly connected with the spatial relationships between residential and services functions in the neighbourhoods.

\section{Confusion about neighbourhood cohesion}

The conceptual inconsistency in defining cohesion in social psychology and geography may rise considerable difficulties in evaluating cohesion at the local level. Some aspects are overlapping and some are contradictory; if we consider the functional ties between residents and their attitudes towards the neighbourhood, we perceive space merely as a background to those phenomena. On the other hand, when we focus on the spatial dimension of cohesion, social interactions seems to be an outcome of particular distribution of opportunities in space. Thus the traditional approach to neighbourhood cohesion is missing territorial dimension whereas the territorial cohesion concept cannot be applied to neighbourhoods due to its focus on large-scale spatial units.

Therefore the main aim of this paper is to complement the state-of-the-art by developing an integrated approach including both social and spatial aspects of cohesion at the local level. Such revision of knowledge is necessary for building a comprehensive and universal understanding of neighbourhood cohesion.

\section{Methods}

Measurement of neighbourhood characteristics is not simple. Neighbourhoods are both geographic and social units, and typically their boundaries are not obvious and may even be contentious. The researcher has to consider the feasibility of collecting data, 
sampling, ease of observation, or data availability (Ohmer et al., 2019).

This paper is based on secondary data which refers to studies conducted in the years 2017-2019 in five locations in Poland within a research project "Model of the local service centre as a tool for enhancing territorial cohesion of urban areas" at the Faculty of Architecture, Wrocław University of Science and Technology (Damurski 2020; Damurski et al., 2020a; Damurski et al., 2020b). The main research unit is a local service centre (LSC) representing the residents' 'activity space' and examined using its physical, functional and social characteristics (cf. Ohmer et al., 2019).

Each of the local service centres was analysed using the same, standardized research techniques. Three of those techniques are described in this paper, providing a unique mix of methods and thus contributing to a nuanced picture of the studied neighbourhoods. Such approach offers a rich set of comparative, quantitative data and enables drawing reliable answers to the research questions presented in the introduction.

The five case studies

The research sample has been carefully selected in order to represent various settlement contexts, starting from large cities (Warszawa, Wrocław), through medium-sized towns (Ostrów Wielkopolski) down to suburban areas (Siechnice, Zabierzów). It is not random nor representative in statistical terms, but it reflects the purposive approach to community resources research (Ohmer et al., 2019) and offers a good insight into different locations (Fig. 1).

In each neighbourhood a central area (local service centre) has been defined as a place focusing main social and economic activity of residents, forming a multi-functional public space providing access to essential services (Damurski, 2020). The first local service centre is located in Ochota district in Warszawa (area: ca 11 hectares). It is a street market in Mołdawska street with long-lasting traditions, located in a mixed neighbourhood (some 50-year old blocks of flats and some apartments from the last 10 years), accompanied by many services ( 2 discount markets, banks, school, restaurant, library, pharmacy, church etc.). It has a limited access to public transport and poor public spaces system, but there are many well-furbished semi-public courtyards.

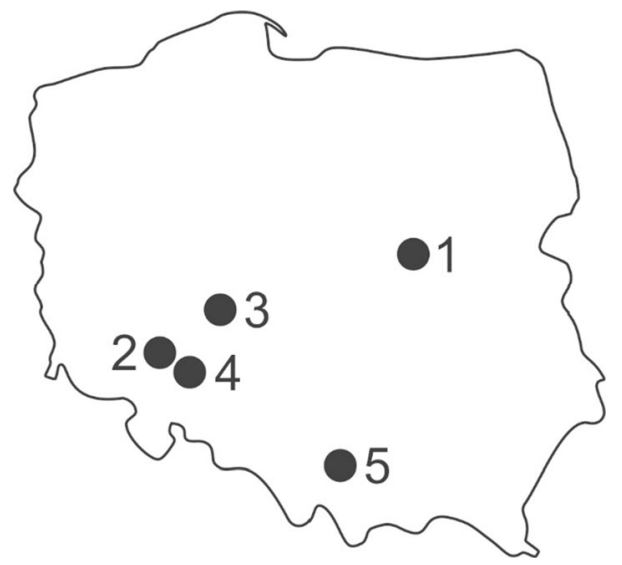

Fig. 1 Location of the case study areas: 1. Warszawa, 2. Wrocław, 3. Ostrów Wielkopolski, 4. Siechnice, 5. Zabierzów. Source: author's own research

The second location is Pereca square in Wrocław (area: ca 12 hectares) with a well-established LSC in a typically urban pre-war neighbourhood offering a variety of services (including discount supermarket, schools, post office, pharmacy, café, bank, library, church) and having a very good access to public transport. Public spaces are in relatively good quality, but dominated by car traffic. The buildings form a mix of old residential quarters, post-socialist blocks of flats and some investments of the last 25 years.

The third example is a well-established cluster of various services in a 40-year old blocks of flats neighbourhood situated around Waryńskiego, Śmigielskiego and Paderewskiego streets in Ostrów Wielkopolski (area: ca 12 hectares). The service sector includes petrol station, discount market, restaurant, pharmacy, small shops, school and church. Public spaces are fragmented and dominated by cars.

The fourth case study is a newly built (2014-2017) market square in Siechnice with the municipality office situated in the central part, surrounded by blocks of flats with some services in the ground floor (area: ca 5 hectares). There is mainly single family housing around the LSC. Inside the area there is a poor or just starting service sector (including street market open Tuesdays, Thursdays and Saturdays, bakery, convenience shop 7-23, bank, café, kindergarten, church), with limited access to public transport but very clear system of public spaces for pedestrians.

The last example is a newly built (2014-2018) market square in Zabierzów (area: ca 11 hectares) with 
a municipality office building. The surrounding buildings are still missing but many various services are offered nearby (supermarket, temporary street market on Saturdays, bank, bakery, café, church, school, sports centre, post office etc.). There is lack of clear pedestrian connections between them. Mainly single family (suburban) housing around and a big national road crossing the area in the southern part are the main characteristics of this case study (Fig. 2).

\section{Social survey}

Social surveys (paper and pencil interviews, PAPI) were conducted among two main groups of respondents: users of public spaces (customers) and services providers. The questionnaire included 12 main questions dealing with respondents' habits and preferences about local environment, plus 5 'metrics' questions including age and their overall situation. The following questions were (directly or indirectly) connected with the issues of territorial cohesion:

- Where do your clients come from? [addressed to services providers];

- Wwhere do you mostly do your everyday personal issues? [addressed to customers];

- How long do you usually travel to this local service centre from your place of residence? Please indicate a standard time in minutes [addressed to customers].

The last question for each group of respondents included a map on which they marked their preferred places: the customers pointed the places where they felt good and the services providers pointed the places where locating a business is most effective.

The questionnaires were distributed by students of the Wrocław University of Science and Technology in selected public spaces and residential areas in each LSC. The distribution was controlled and systematically organised: it was conducted in spring-summer season, in selected weekdays (usually Wednesday and Sunday), in various daytimes (9:00-12:00 and 16:00-19:00), recruiting every 3rd pedestrian or 2 nd resident (within the customers component) or every services provider (within the services providers component). This approach provided necessary standardisation of research and enabled capturing the variety of daily routines and behaviours within each neighbourhood.

A total of 793 filled questionnaires was collected (295 from public space users, 323 from residents and 175 from services providers - see Table 1). The results are presented in three generalized groups, representing different levels of urbanisation: large cities (Warszawa, Wrocław), medium-sized towns (Ostrów

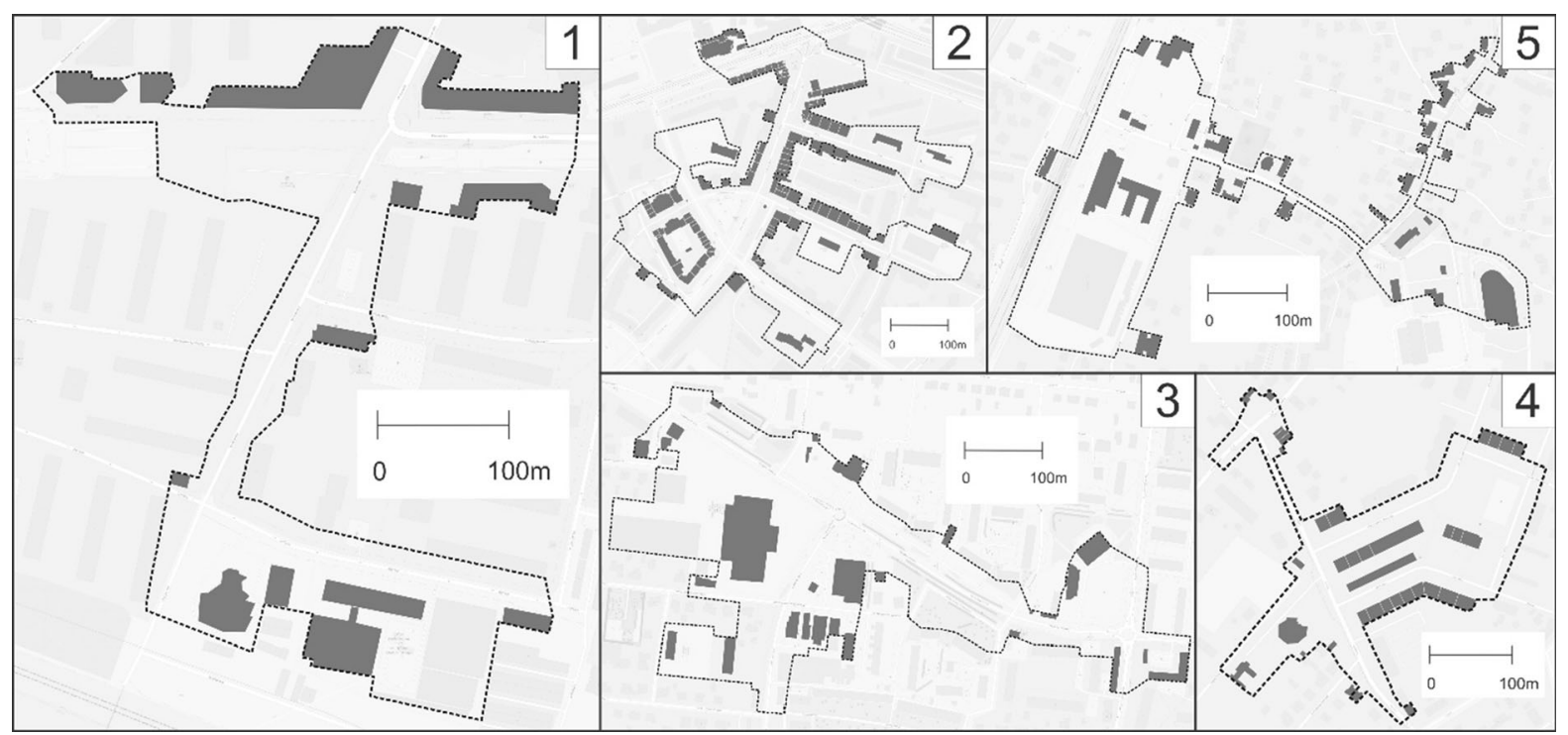

Fig. 2 Local service centres selected for the study: (1) Mołdawska street in Warszawa, (2) Pereca Square in Wrocław, (3) Waryńskiego, Śmigielskiego and Paderewskiego streets in
Ostrów Wielkopolski, (4) Rynek in Siechnice, (5) Kolejowa and Krakowska streets in Zabierzów. Source: (Damurski et al., 2020a) [used with permission] 
Table 1 Number of questionnaires filled in particular locations

\begin{tabular}{|c|c|c|c|c|c|}
\hline \multicolumn{2}{|c|}{ Local service centre } & \multicolumn{4}{|c|}{ Number of respondents } \\
\hline \multirow[t]{2}{*}{ Location } & \multirow[t]{2}{*}{ Name } & \multicolumn{2}{|c|}{$\begin{array}{l}\text { Customers and users of public } \\
\text { spaces }\end{array}$} & \multicolumn{2}{|c|}{$\begin{array}{l}\text { Services } \\
\text { providers }\end{array}$} \\
\hline & & Number & $\%$ & Number & $\%$ \\
\hline \multirow[t]{2}{*}{ Large cities } & Warszawa: Mołdawska street & 161 & 26.1 & 43 & 24.6 \\
\hline & Wrocław: Pereca square & 159 & 25.7 & 58 & 33.1 \\
\hline Medium towns & Ostrów Wielkopolski: Waryńskiego street and surroundings & 135 & 21.8 & 28 & 16.0 \\
\hline \multirow[t]{2}{*}{ Suburban areas } & Siechnice: market square & 73 & 11.8 & 16 & 9.1 \\
\hline & Zabierzów: Kolejowa street and surroundings & 90 & 14.6 & 30 & 17.1 \\
\hline Total & & 618 & 100.0 & 175 & 100.0 \\
\hline
\end{tabular}

Source: (Damurski et al., 2020a, 2020b) [used with permission]

Wielkopolski) and suburban areas (Siechnice, Zabierzów). This research sample is not representative in statistical terms which means that the results cannot be generalized for the whole population. However, it is methodologically sound and allows making some general remarks on neighbourhood characteristics.

Geocoding, processing and visualizing

The results of the social survey have been geocoded as points with particular geographical coordinates, forming a unique spatial database. This database served as a basis for the maps of attractiveness of public spaces in the five case study areas.

Graphical visualization of the results was conducted using GIS applications by adopting a distancedependent density estimation tool (Kernel shape). This method enables a non-parametric surface smoothing of the distribution of respondents' answers (Silverman, 1986). The size of computing cells (X, Y) was established at $10 \mathrm{~m}$, representing an average social distance (Hall, 1997) and the range of analysed local service centres. The parameters have been standardized for each of the locations which enables comparisons despite significant differences in the number of respondents (Damurski et al., 2020b).

Following geocoding, a second GIS analysis has been conducted in order to match the answers of the customers and of services providers. A reclassification procedure was used to transform raster files into geodata polygon files. Then the areas pointed by users $\left(d_{\text {use }}\right)$ were merged with areas pointed by services providers $\left(d_{s e r}\right)$ and areas preferred by both groups were extracted. As a result, a convergence ratio $(C R)$ was counted using the following equation:

$C R=\frac{d_{\text {int }}}{d_{\text {uni }}}$

where $d_{\text {uni }}=d_{\text {ser }}+d_{\text {use }}($ Union $)$. and $d_{\text {uni }}=d_{\text {ser }} \times d_{\text {use }}$ (Intersection $)$.

Accessibility analysis

Accessibility studies are quite common in measuring various aspects of neighbourhood performance, such as school catchment areas (Harris \& Johnston, 2008), green areas proximity (Leonard et al., 2015), playground congestion (Martori et al., 2020) or food provision (Renee et al., 2021). The accessibility analyses presented in this paper are based on a classic time- and space-related geography (Hägerstrand, 1970), which uses time units representing the ease of reaching activities distributed in particular area (Bryniarska \& Starowicz, 2010). Juxtaposition of destinations (in this case homes and service points) and constraints that affect penetration of space (e.g. buildings, water or highways) allows to conduct comparative analysis of various areas.

Thus, linking the speed of movement, diversity of possible routes and impedance of space existing in particular area, can produce a quite realistic picture of time-space accessibility expressed by isochroneslines of equal time. Such study requires: (1) points representing the location of customers; (2) target points representing the distribution of service nodes 
and (3) means of transport, including their routes and morphology of a particular territory (Guzik, 2003).

In this research ArcGIS tool called Network Analyst module has been used, which allowed to conduct the 'shortest path' analysis and to designate catchment areas of services. Network Analyst returns a group of coherent edges of the network, which represent a defined spatial accessibility for the assumed impedance.

The pedestrian network covered all LSC areas where walking is possible (including sidewalks, park alleys, gates in buildings, squares, stairs, etc.). The data was retrieved from digital maps provided by municipalities and public geodesy offices, and validated via fieldwork. The potential speed of movement assigned to particular sections of the network was estimated at an average of $3500 \mathrm{~m}$ per hour.

Another key parameter of accessibility is the 'critical range of contact', i.e. the maximum isochrone for trips to services. This critical range is related to spatial distribution of services, quality of transportation system, average speed of users and customers' preferences. In this study it was set at 5 and $10 \mathrm{~min}$. Another important parameter is the number of population within specified isochrone. It can be obtained directly from public statistical resources or estimated by considering the average population density and types of residential buildings. In this study the second approach was adopted.

\section{Addressing the research questions}

The methodological framework presented above has a good potential to address the research questions. The first issue-describing the relationships between the concepts of territorial cohesion and neighbourhood cohesion in particular contexts-requires acquiring both social and spatial data for the selected locations. Using social survey, geocoding and accessibility analysis provides a multidisciplinary set of necessary data. The second question — searching for the ways of measuring neighbourhood cohesion using territorial perspective-needs to be based on a diverse but comparable research sample. Selecting neighbourhoods representing large cities, medium-sized towns and suburbs enables drawing reliable conclusions regarding the territorial cohesion measurement methods.

\section{Results}

Neighbourhood cohesion means self-containment

According to the classical theory of central places (Christaller, 1993) there is a hierarchy of services in human settlements, ranging from low-order ones through intermediate to high-order ones and offering different goods. Clients travel a short distance to access low-order services: these services are used frequently, they have relatively low value and require little skill to produce. Clients potentially travel longer distances in order to access intermediate services: they are used less frequently and are of higher value. Finally, very long distances are considered in order to reach the high-order services that are very specialised and used sporadically by clients (Shearmur, 2010).

A spatial database for each of the five neighbourhoods based on maps (retrieved from geodesy and cadastral institutions as well as Open Street Map) and on on-site inventory enabled quantification of available facilities. The neighbourhood services were divided into seven categories: grocery shops, postal and financial services (post office, bank), healthcare (GP, clinic, ambulatory), gastronomy (café, bar, pub, restaurant), education (schools, kindergartens), administrative (institutional) services, other services (culture, hairdresser, beauty, fitness etc.). Table 2 shows the distribution of particular categories in the five analysed LSC's.

As it is visible in the table, the number of services decreases with the size of settlement where particular LSC is located. The highest density of amenities is observed in Warszawa, and the lowest in Ostrów Wielkopolski, due to quite wide spatial range of this LSC.

This research focuses is on the local (neighbourhood) level, where essential amenities are located. In order to precisely distinguish them from higher-order services the respondents were asked to allocate particular functionalities they realise in their neighbourhoods to one of four categories: in this LSC, near this LSC, in other neighbourhood/district and in other town/city. The results show that the most common functions realised in the LSC are small (everyday) shopping $(60.2 \%)$, postal services $(59.5 \%)$, financial services (banks, cash machines, 41.5\%), larger (weekly) shopping (32.4\%) and spending free time with family (25.9\%). Near the LSC respondents use 
Table 2 Statistics on amenities and public transport nodes available in the 5 studied locations
Source: (Damurski et al., 2020) [used with permission]

\begin{tabular}{llllll}
\hline Amenities & Warszawa & Wrocław & Ostrów Wlkp & Siechnice & Zabierzów \\
\hline Grocery shops & 43 & 24 & 11 & 6 & 6 \\
Specialized services & 35 & 45 & 37 & 7 & 23 \\
Healthcare & 2 & 10 & 5 & 3 & 3 \\
Gastronomy & 6 & 6 & 4 & 5 & 4 \\
Education & 2 & 4 & 5 & 2 & 5 \\
Institutional services & 5 & 7 & 6 & 7 & 12 \\
Other services & 12 & 24 & 13 & 7 & 8 \\
Total & 105 & 120 & 81 & 37 & 61 \\
Area [ha] & 6.73 & 10.45 & 12.63 & 5.23 & 9.19 \\
Density of amenities [per 1 ha] & 15.6 & 11.48 & 6.41 & 7.07 & 6.64 \\
\hline
\end{tabular}

healthcare services (GP, ambulatory, clinic, 35.5\%) and other services (culture, haircutter, beauty, fitness, florist, 31.8\%). Functions conducted mostly outside the LSC are meeting friends $(32.7 \%)$ and eating out (bar, restaurant, café, 27.3\%). Other categories, such as walking with children, open air physical activity (jogging, nordic walking), walking a dog or bringing children to and picking up from school/kindergarten remain unclassified.

The number of needs satisfied inside the LSC, near the LSC and outside the LSC may be a useful measure of how self-contained are LSC's. The so called 'balance of functions' is presented in Table 3.

The results are surprisingly different from the statistics presented in Table 2. All the analysed LSC's satisfy most of the needs within or near their borders. However, despite relatively low density of amenities available in the LSC in medium-sized town, this centre satisfies most of the users' needs in place. On the contrary, large city examples are less self-contained in the users' opinion, in spite of high number of service points located within their borders.

The functions performed by the LSCs are mostly determined by the diversity of services offered. Service providers, adapting to the needs of their customers and reacting to market changes, shape the character of a neighbourhood service centre. The appropriate range of goods and services available determines satisfying daily needs and thus animates the neighbourhood by attracting residents.

Most of the service providers in selected localisations are small enterprises operating on a local scale. However, the local character of an LSC is not only acquired by the dominance of traditional trade or the presence of local brands. It is also built by the proximity of the customers and the knowledge about them. That is why the respondents-service providers-were asked whether they knew where their customers came from (Fig. 3).

It is possible to indicate some interesting relationships between the type of an LSC and the customers'

Table 3 The balance of functions realized by respondents inside and outside the LSC by settlement type

\begin{tabular}{llll}
\hline Feature & $\begin{array}{l}\text { Large cities } \\
\text { (Warszawa and } \\
\text { Wrocław) }\end{array}$ & $\begin{array}{l}\text { Medium-sized town } \\
\text { (Ostrów Wielkopolski) }\end{array}$ & $\begin{array}{l}\text { Suburbs (Siechnice } \\
\text { and Zabierzów) }\end{array}$ \\
\hline $\begin{array}{l}\text { Average number of needs satisfied in the LSC and } \\
\text { near the LSC (range 0-13) }\end{array}$ & 5.8 & 9.5 & 6.8 \\
$\begin{array}{l}\text { Average number of needs satisfied outside the } \\
\text { LSC }\end{array}$ & 3.2 & 0.3 & 4.7 \\
$\begin{array}{l}\text { Difference between the average number of needs } \\
\text { satisfied in the LSC and outside the LSC }\end{array}$ & 2.6 & 9.1 & 3.0 \\
\hline
\end{tabular}

Source: (Damurski, 2020) [used with permission] 
Fig. 3 Service providers' knowledge of their customers' place of residence by settlement type. Source: (Damurski, 2020) [used with permission]

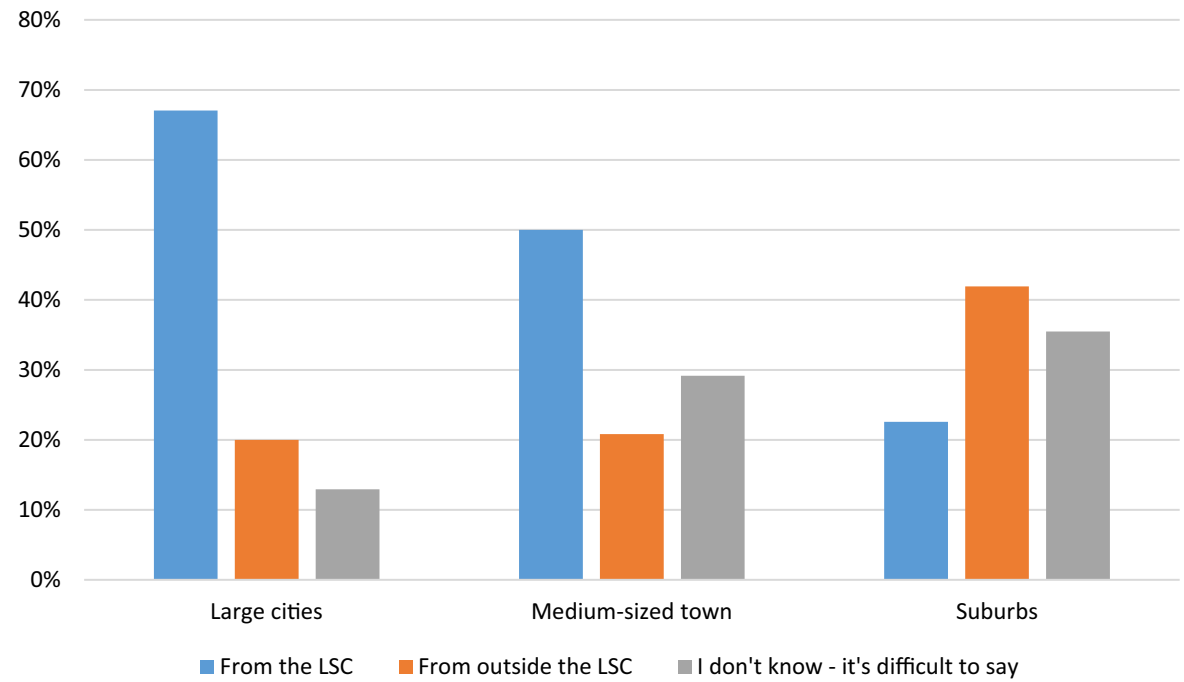

characteristics: LSCs within large cities seem to be the most 'local' ones. Both in the case of Pereca Square in Wrocław and the marketplace on Mołdawska Street in Warsaw, service providers indicated the prevalence of customers coming directly from the neighbourhood where LSC is located. In the two cases also the percentage of respondents unable to specify their customers' residence was the lowest. For the mediumsized town, and especially for the suburban LSCs, the percentage of customers from the neighbourhood was decreasing and the degree of ignorance about them was higher.

Hence, this study offers ambiguous results. On one hand the functional self-containment of LSCs is mostly observed in medium-sized town which may suggest that neighbourhood cohesion is highest in this type of settlements. On the other hand social ties between local customers and services providers are relatively stronger in large cities than in other locations. This ambiguity requires further examination.

Neighbourhood cohesion means accessibility of everyday services

The results of the social survey show that most of the respondents arrive at the LSC by foot (453 persons), some of them by car (117 people, mainly in Ostrów Wielkopolski) and some by public transport (100 people). Only several respondents (59) arrive by bike. Notwithstanding the mean of transport, most users reach the LSC in $5 \mathrm{~min}$ (58.6\% of answers) and therefore may be considered as local residents. However, there is a quite big group of users who arrive from larger distances (263 respondents, 36.0\%), probably due to low accessibility of services in their area of residence or due to outstanding attractiveness of services offered in the studied LSC.

This study focuses on pedestrian movement as the most natural way of penetrating neighborhood areas. The 5- and 10-min walking zones presented on the outcome maps (Fig. 4) show spatial ranges of the isochrones in each LSC. Residents living in particular zone have access to at least one of the seven categories of services (Table 2) located within particular time distance.

A simple observation of the urban tissue in each of the time zones suggests that areas situated closer to the LSC are characterized by higher density of buildings than those located further away. This observation is confirmed by the population distribution: despite much bigger area of the 10-min zone, in each neighbourhood the density of population is decreasing with the distance from the centre (Fig. 5).

Such relationship between services accessibility and housing structure reflects a natural concentration mechanism that has been present in human settlement processes from the very beginning. It also brings an important input into the debate on territorial cohesion: providing access to local services within particular isochrones seems to be a good measure for just distribution of opportunities in space. 


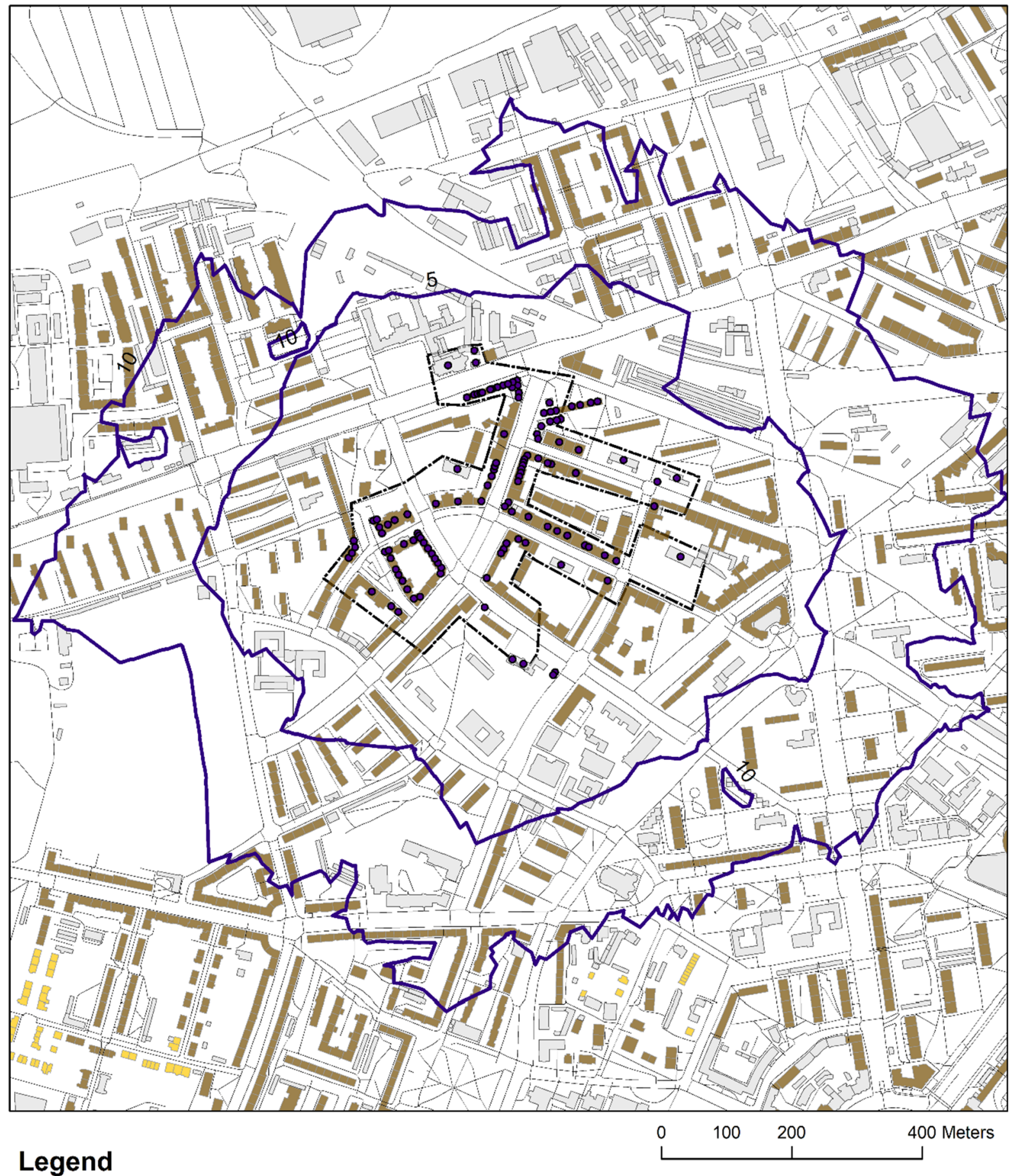

- services localization

— service range $(5 ; 10 \mathrm{~min}$ ) pedestrian transportation system [_._._._area of local service centre all other buildings

single-family residential buildings

buildings with two apartments

multi-family houses 
4 Fig. 4 Sample map of the 5- and 10-min pedestrian isochrones for LSC Wroclaw: Pereca square. Source: (Damurski et al., 2020a) [used with permission]

Neighbourhood cohesion means matching demand and supply

Visualisation of customers' and services providers' spatial preferences (Fig. 6) demonstrates significant differences in the approach of each of the studied groups. Concentration of positive answers given by the users may be interpreted as ,places of local community" where particular emotional ties are located (Agnew, 1987). On the contrary, spatial preferences of services providers are based on economic characteristics of space, such as catchment area, market capacity and land value. In theory, the two groups should meet in one place in order enable comfortable interaction and to satisfy their needs. In practice, the picture of attractiveness of local service centres is more complex: most customers prefer open squares whereas most services providers point streets and passages.

Spatial preferences of services providers are characterized by two features. First, there is a visible tendency to highly evaluate areas where pathways of customers get crossed: main crossroads and streets with high traffic volumes are the most attractive places (LSC in Zabierzów and in Ostrów Wlkp.). This feature is partly connected with parking spaces-for example in LSC in Wroclaw services are located mainly in Pereca Street where places for cars are provided, not in nearby Grabiszyńska Street where the highest traffic load is observed (cf Mayer-Wydra, 2019).

The second feature typical for services providers is the existence of other amenities, especially those with long history. New shops and cafes are preferably located near the previously built ones which is supposed to raise the number of potential clients. For example in LSC in Warsaw the street market became a reference point for many other places indicated by the services providers.

The results for customers show that neighbourhood attractiveness may be connected with a general notion of spatial order and aesthetics. The mostly preferred areas are greenery (a park near the LSC in Warsaw, playground in LSC in Wroclaw) and public squares (LSCs in Siechnice and Zabierzów). Each of those places has been quite recently refurbished and probably this "newness" is the main reason for such preferences.

Hence there is a visible dispersion of areas preferred by each group. Juxtaposition of the quantified spatial preferences of customers and services providers reveals relatively low levels of convergence
Fig. 5 Average estimated population in accessibility zones by settlement type. Source: (Damurski et al., 2020a) [used with permission]

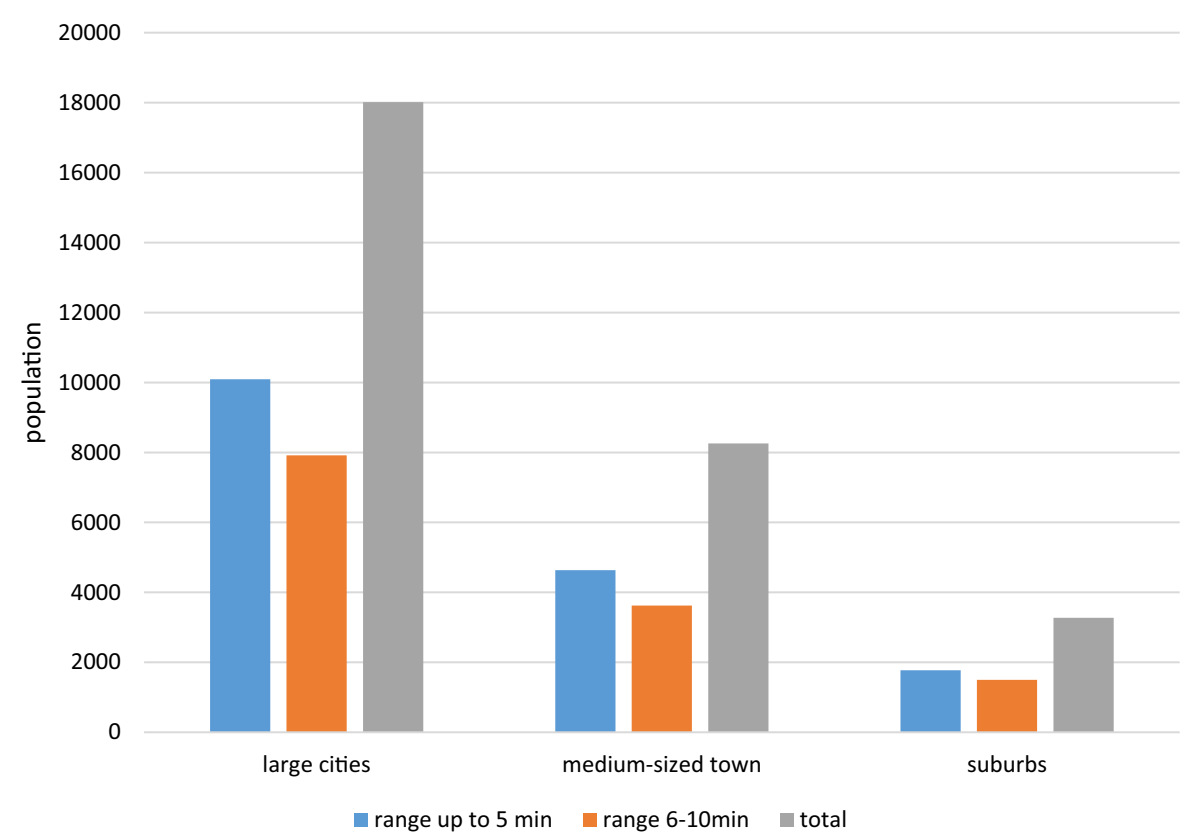



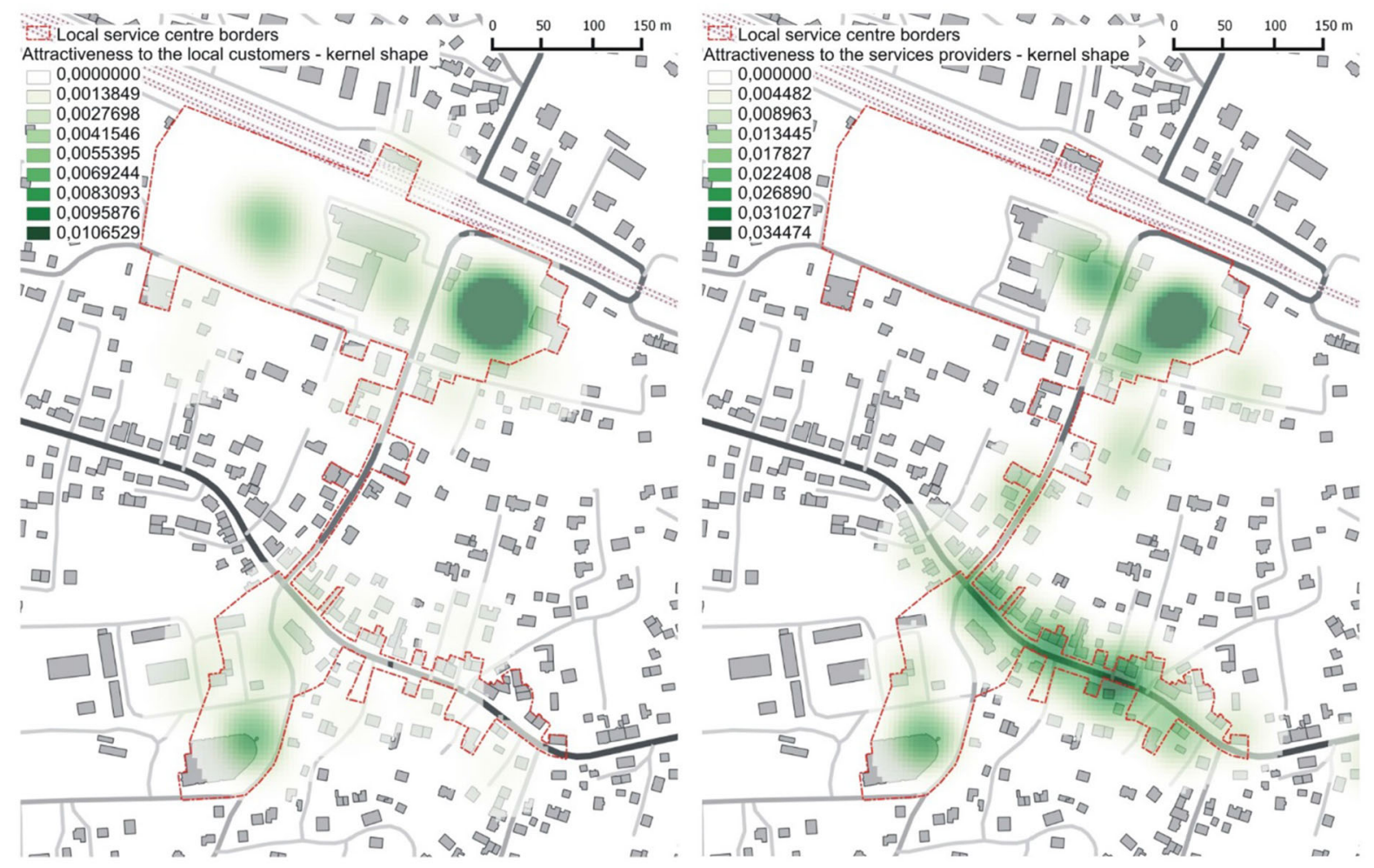

Fig. 6 Sample visualisation of answers of customers (left) and services providers (right) in Zabierzów local service centre. Source: (Damurski et al., 2020b) [used with permission]

in each location: the $\mathrm{CR}$ values reach from 0.14 to 0.21 (Table 4). The preferences of customers and of services providers are significantly different, in particular in Zabierzów case study.
Despite the differences described above, there are several commonalities in perception of space by the users and by the services providers: in each local service centre there are at least two concentrations of positive answers from both groups (Fig. 7). Even

Table 4 Convergence between customers' and services providers' answers regarding the attractiveness of neighbourhood public spaces

\begin{tabular}{|c|c|c|c|c|}
\hline \multicolumn{2}{|c|}{ Local service centre } & \multicolumn{2}{|l|}{ Areas preferred by } & \multirow{2}{*}{$\begin{array}{l}\text { Convergence } \\
\text { ratio } \\
C R\end{array}$} \\
\hline Location & Name & $\begin{array}{l}\text { Either users or services } \\
\text { providers } \\
d_{\text {uni }} \\
\mathrm{m}^{2}\end{array}$ & $\begin{array}{l}\text { Both users and services } \\
\text { providers } \\
d_{\text {int }} \\
\mathrm{m}^{2}\end{array}$ & \\
\hline \multirow[t]{2}{*}{ Large cities } & Warszawa: Mołdawska street & $89,922.42$ & $16,200.00$ & 0.18 \\
\hline & Wrocław: Pereca square & $39,952.12$ & 8526.92 & 0.21 \\
\hline $\begin{array}{l}\text { Medium } \\
\text { towns }\end{array}$ & $\begin{array}{l}\text { Ostrów Wielkopolski: Waryńskiego street } \\
\text { and surroundings }\end{array}$ & $88,870,37$ & $17,982.90$ & 0.20 \\
\hline \multirow{2}{*}{$\begin{array}{c}\text { Suburban } \\
\text { areas }\end{array}$} & Siechnice: market square & $21,105.21$ & 3775.17 & 0.18 \\
\hline & Zabierzów: Kolejowa street and surroundings & $41,227.19$ & 5883.28 & 0.14 \\
\hline
\end{tabular}

Source: (Damurski et al., 2020b) [used with permission] 
though it is hard to prove any regularity in location of particular zones, one observation seems to be indicative: open public spaces, equipped with greenery, clear pathways for pedestrians and surrounded by buildings with services on the ground floor are commonly pointed by both groups. This observation proves the indispensable role of LSC for neighbourhood liveability.

\section{Limitations of the study and further research directions}

This paper is a selective overview of possible solutions enabling quantification of spatial dimension of cohesion at the local level. Its aim is to complement the traditional socio-psychological understanding of neighbourhood cohesion with necessary geographical references. Hence it does not provide one, comprehensive, ready-to-use analytical tool for evaluating neighbourhood cohesion taking territorial perspective.

The main limitations of the study are connected with scarce research sample, including only five neighbourhoods in Poland. Further research would be required to verify the results in other social and spatial contexts.

Also the proposed interdisciplinary approach is lacking scientific rigor. It is just a simple juxtaposition of findings from various disciplines, acquired using different research methods and conceptual frameworks. More scrutiny in referring and comparing the results obtained by various researchers would contribute to higher reliability of the paper.

However, despite the disadvantages described above, the study offers a valuable insight into applying the concept of territorial cohesion to the neighbourhood level. It can be a starting point for further research in urban geography and urban planning, in particular dealing with services provision and optimization of neighbourhood functional structures.

\section{Discussion}

The results of this study do not defy prior research (in particular by Buckner, 1988), but they show a possible link between the primary understanding of neighbourhood cohesion and contemporary policies related to territorial cohesion. Cohesion as a feature of a neighbourhood is thus not only about its community ties (Colombo et al., 2001), networking (Talen, 2000), emotional bond with a place (Scannell \& Gifford, 2010) nor about its spatial structure (cf Youssef, 2015). It is also about its functional features, accessibility of particular amenities and relations between the needs of community and provision of services.

The examples presented in this paper prove that those features can be effectively measured and compared between neighbourhoods representing various settlement types. Through a systematic analysis of functional balance, accessibility parameters and supply-demand relationships it is possible to draw a selective but reliable picture of territorial cohesion on the local level (cf Damurski et al., 2020a). As a result, an integrated vision of neighbourhood cohesion emerges, including both social and spatial aspects of cohesion at the local level (Table 5), strengthening the complementarity of the two approaches.

In the case of five local service centres investigated in this study and located in various urban contexts in Poland, the best results were obtained for large-cities where the density of various amenities and the number of population living near the LSC is the highest, the relationships between supply and demand are wellestablished and the convergence between spatial preferences of customers and services providers is the highest. However, in medium-sized town the balance of functions related to everyday needs is most positively evaluated by the residents which gives the town a privileged position in the neighbourhood cohesion rankings. The lowest levels of neighbourhood cohesion have been noted in suburban settlements which confirms their malfunctioning character described in the literature.

Thus, the paper fills an important gap in the to-date knowledge by building a consistent, integrated methodological approach to neighbourhood cohesion. The presented analyses, implementing both social and spatial aspects of cohesion at the local level, contribute to the neighbourhood research and offer a clear reference to the principles of cohesion policy.

\section{Conclusions}

Each neighbourhood is a unique amalgamate of interrelated geographic and social features. Scientific measurement of those features is a big challenge, 


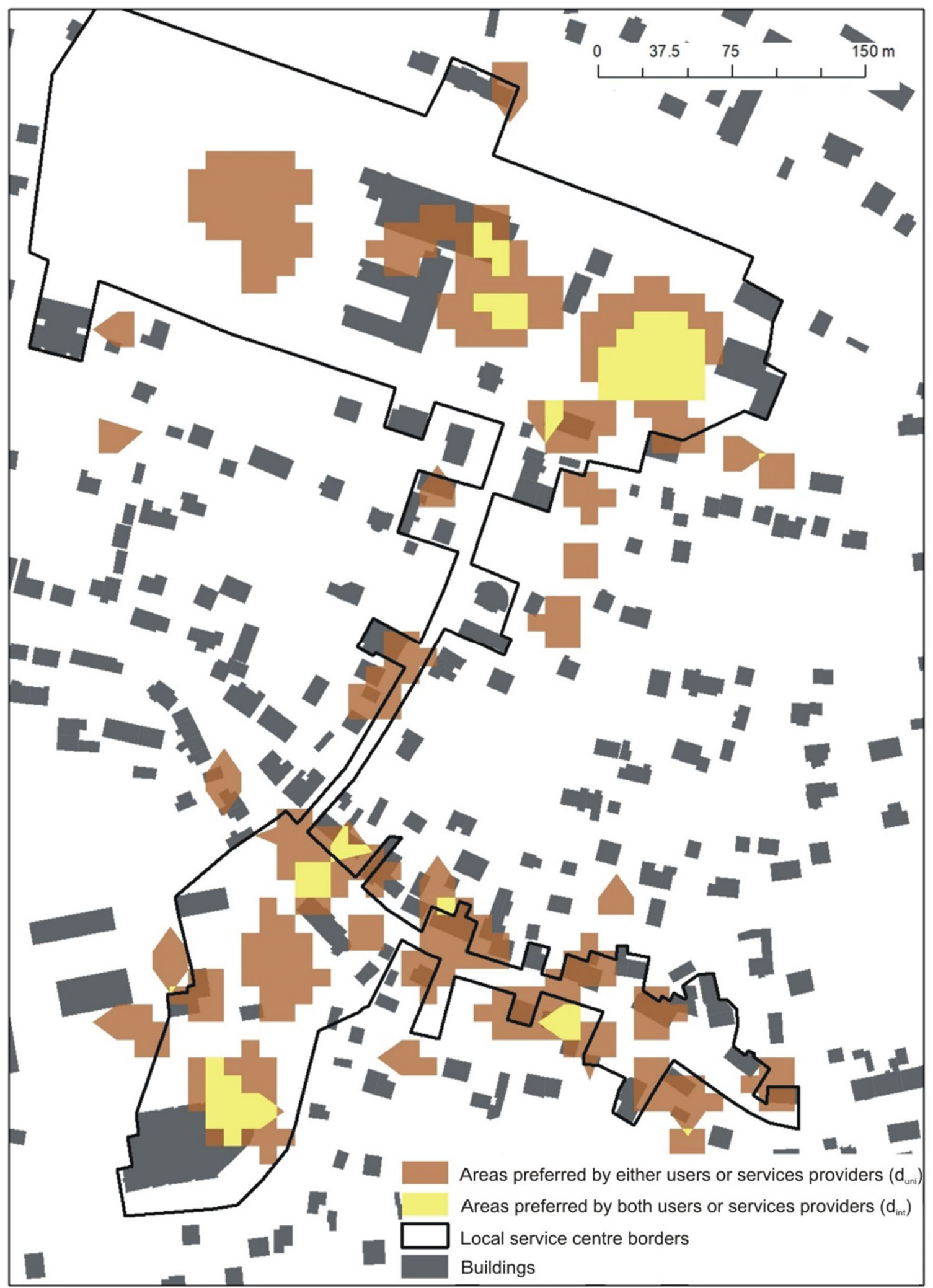


4Fig. 7 Areas positively evaluated by customers and services providers. Example of Zabierzów local service centre. Source: (Damurski et al., 2020b) [used with permission]

especially when conceptual consistency between various disciplines is missing. In this paper the concept of neighbourhood cohesion has been examined, starting from its original meaning (embedded in social sciences) and then linking it to current policy developments (embedded in socio-economic geography).

The two research questions outlined in the introduction have been answered in the following ways:

(Q1) The relations between the concepts of territorial cohesion and neighbourhood cohesion are twofold: some of their aspects are overlapping and some are contradictory. The traditional (socio-psychological) approach to neighbourhood cohesion, despite its endeavours to respect spatial structures (cf the role of the environment in An \& Western research of 2019), is missing territorial dimension; the territorial cohesion concept (embedded in socio-economic geography) tries to include social aspects of development but cannot be applied to neighbourhoods due to its original focus on large-scale spatial units (Dao et al., 2017).

The proposed rethinking of neighbourhood cohesion leaded to a comprehensive, joint approach which says that cohesion at the local level depends upon perceived functional self-containment of a neighbourhood, accessibility of essential services (both public and private) and appropriate balance between demand and supply observed in particular area.

(Q2) The second question-searching for the ways of measuring neighbourhood cohesion using territorial perspective - was addressed by adopting a mixed-method research, including social survey, geocoding and accessibility analysis. Selecting neighbourhoods which represented various settlement contexts enabled a systematic, comparative analysis of the core features of neighbourhood cohesion: functional balance, accessibility and supply-demand relationships.

The proposed approach enhances the concept of neighbourhood cohesion and contributes to its comprehensiveness. Such revision seems to be a necessary step towards building a holistic conceptual framework for urban planning, ultimately involving both sociopsychological and geographical aspects of the cohesion phenomenon. It also makes the political idea of territorial cohesion more applicable at the local level.

The values of such vision of neighbourhood cohesion can be descriptive (when one wants to evaluate the level of cohesion of particular area) or normative (when one wants to set goals for public policy). However, a neighbourhood presenting high levels of neighbourhood cohesion cannot be considered as an isolated entity. Even if it is well equipped with particular amenities and positively evaluated by its residents, it should be always perceived as an element of a wider network, linked both to other local service centres and to higher-level urban hubs.

Table 5 Juxtaposition of neighbourhood cohesion measures in socio-psychological sciences and in geographical sciences

\begin{tabular}{|c|c|c|c|}
\hline \multicolumn{2}{|c|}{ Social and psychological measures } & \multicolumn{2}{|l|}{ Geographical measures } \\
\hline Measure & $\begin{array}{l}\text { Resulting neighbourhood } \\
\text { characteristics }\end{array}$ & Measure & $\begin{array}{l}\text { Resulting neighbourhood } \\
\text { characteristics }\end{array}$ \\
\hline $\begin{array}{l}\text { Psychological sense of } \\
\text { community }\end{array}$ & $\begin{array}{l}\text { Social ties and social } \\
\text { integration }\end{array}$ & Functional balance & Self-containment and functionality \\
\hline $\begin{array}{l}\text { Attraction-to- } \\
\text { neighbourhood }\end{array}$ & $\begin{array}{l}\text { Territorial identification } \\
\text { and local identity }\end{array}$ & Accessibility of services & Quality of life and walkability \\
\hline $\begin{array}{l}\text { Social interaction within a } \\
\text { neighbourhood }\end{array}$ & $\begin{array}{l}\text { Social capital and civic } \\
\text { values }\end{array}$ & $\begin{array}{l}\text { Spatial relationships between } \\
\text { supply and demand }\end{array}$ & $\begin{array}{l}\text { Local market condition and adequacy } \\
\text { of spatial structures }\end{array}$ \\
\hline
\end{tabular}

Source: Author's own research 
Acknowledgements I would like to express my gratefulness to my colleagues: Jacek Pluta (University of Wrocław), Wawrzyniec Zipser (Wrocław University of Science and Technology) and Magdalena Mayer-Wydra (University of Wrocław) who shared their knowledge with me, conducted empirical research and inspired me to reflect on the meaning of neighbourhood cohesion. Our cooperation within a research project "Model of the local service centre as a tool for enhancing territorial cohesion of urban areas" at the Faculty of Architecture, Wrocław University of Science and Technology in the years 2016-2020, financed by the National Science Centre Poland under Grant number 2015/19/B/HS4/01301, was very fruitful and gave me a solid background to write this paper.

Funding The research leading to these results received funding within research project "Model of the local service centre as a tool for enhancing territorial cohesion of urban areas" conducted at the Faculty of Architecture, Wrocław University of Science and Technology in the years 2016-2020, financed by the National Science Centre Poland under Grant Number 2015/19/B/HS4/01301.

\section{Declarations}

Conflict of interest I declare that no conflict of interest in terms of funding, employment, financial interests nor non-financial interests is in place for the manuscript "Neighbourhood Cohesion And Territorial Cohesion: In Search For Conceptual Integrity". The author has no relevant financial or non-financial interests to disclose. He has no conflicts of interest to declare that are relevant to the content of this article. He certifies that he has no affiliations with or involvement in any organization or entity with any financial interest or non-financial interest in the subject matter or materials discussed in this manuscript. He has no financial or proprietary interests in any material discussed in this article.

Consent to participate All the participants of the social survey conducted in selected neighbourhoods were informed about their contribution to the research project and agreed to do so.

Consent for publication The paper includes some tables and figures published in other scientific works. All the copyright owners have agreed for the reprint of particular items when the paper was submitted first for "Applied Spatial Analysis Journal" in March 2021. Relevant correspondence is available at request.

Human or animals participants This research included a social survey involving customers and services providers in the selected neighbourhoods in Poland. All participants were informed about their contribution to the research project and agreed to do so.

Open Access This article is licensed under a Creative Commons Attribution 4.0 International License, which permits use, sharing, adaptation, distribution and reproduction in any medium or format, as long as you give appropriate credit to the original author(s) and the source, provide a link to the Creative Commons licence, and indicate if changes were made. The images or other third party material in this article are included in the article's Creative Commons licence, unless indicated otherwise in a credit line to the material. If material is not included in the article's Creative Commons licence and your intended use is not permitted by statutory regulation or exceeds the permitted use, you will need to obtain permission directly from the copyright holder. To view a copy of this licence, visit http://creativecommons.org/licenses/by/4.0/.

\section{References}

Agnew, G. J. (1987). Place and politics: The geographical mediation of state and society. Allen and Unwin.

An, W., \& Western, B. (2019). Social capital in the creation of cultural capital: Family structure, neighborhood cohesion, and extracurricular participation. Social Science Research, 81(2019), 192-208. https://doi.org/10.1016/j.ssresearch. 2019.03.015

Bryniarska, Z. and Starowicz W. (2010). Wyniki badań systemów publicznego transportu zbiorowego w wybranych miastach, SITK, Kraków.

Buckner, J. C. (1988). The Development of an Instrument to Measure Neighborhood Cohesion. American Journal of Community Psychology, 16(6), 771-791. https://doi.org/ 10.1007/BF00930892

Christaller, W. (1993). Die zentralen Orte in Süddeutschland, Gustav Fischer, Jena.

Clifton, J., Díaz-Fuentes, D., \& Fernández-Gutiérrez, M. (2016). Public Infrastructure Services in the European Union: Challenges for Territorial Cohesion. Regional Studies, 50(2), 358-373.

Colombo, M., Mosso, C., \& De Piccoli, N. (2001). Sense of community and participation in urban contexts. Journal of Community \& Applied Social Psychology, 11(6), 457-464. https://doi.org/10.1002/casp.645

European Commission (2004). A new partnership for cohesion convergence competitiveness cooperation. Third report on economic and social cohesion. European Communities.

Damurski, Ł. (Ed.). (2020). Model lokalnego centrum usługowego jako narzędzie kształtowania spójności terytorialnej obszarów miejskich, Wrocław: Oficyna Wydawnicza Politechniki Wrocławskiej.

Damurski, Ł, Pluta, J., \& Zipser, W. (2020a). Pedestrian accessibility of services as a measure of territorial cohesion at the neighbourhood level. Bulletin of Geography. SocioEconomic Series, 49(49), 31-48. https://doi.org/10.2478/ bog-2020-0022

Damurski, Ł., Mayer-Wydra, M., Komorowska, K. (2020b). Spatial dimension of neighbourhood liveability. Combined perspective of local customers and services' providers. "Studia Miejskie", 37 (2020), 11-22. https://doi.org/10. 25167/sm.1471

Dao, H., Cantoreggi, P., \& Rousseaux, V. (2017). Operationalizing a contested concept: Indicators of territorial cohesion. European Planning Studies, 25(4), 638-660. https://doi.org/10.1080/09654313.2017.1281230

ESPON (2012). INTERCO. Indicators of territorial cohesion. Scientific Platform and Tools Project 2013/3/2. Final 
Report. Part A. Executive summary. ESPON \& University of Geneva, Luxembourg.

Faludi, A. (2007). Territorial Cohesion and the European Model of Society (Cambridge, MA: Lincoln Institute of Land Policy).

Guzik, R. (2003). Przestrzenna dostępność szkolnictwa ponadpodstawowego, Wydawnictwo Instytutu Geografii i Gospodarki Przestrzennej Uniwersytetu Jagiellońskiego, Kraków.

Hägerstrand, T. (1970). What about people in Regional Science. Papers of the Regional Science Association, Vol. XXIV: $7-21$.

Hall, E. (1997). „Ukryty wymiar”, Warszawskie Wyd. Literackie MUZA SA.

Harris, R., \& Johnston, R. (2008). Primary schools, markets and choice: Studying polarization and the core catchment areas of schools. Applied Spatial Analysis, 2008(1), 59-84. https://doi.org/10.1007/s12061-008-9002-8

Interreg: European Territorial Co-operation (2021). Website: https://ec.europa.eu/regional_policy/en/policy/ cooperation/european-territorial/ (accessed 2021.09.13).

Leonard, T., Zhang, L., \& Hoehner, C. (2015). Variations in park facility valuations across neighborhoods. Applied Spatial Analysis, 2015(8), 45-67. https://doi.org/10.1007/ s12061-014-9120-4

Martori, J. C., Apparicio, P., \& Séguin, A.-M. (2020). Spatial potential accessibility of playgrounds in Barcelona City. Applied Spatial Analysis and Policy, 2020(13), 489-506. https://doi.org/10.1007/s12061-019-09316-4

Mayer-Wydra M. (2019). Wzorce struktury hierarchicznej miejskich układów handlowych na tle transformacji ustrojowej. Badania na przykładzie wybranych miast polskich. Praca doktorska. Politechnika Wrocławska.

Nosek, Š. (2017). Territorial cohesion storylines in 2014-2020 Cohesion Policy. European Planning Studies, 25(12), 2157-2174. https://doi.org/10.1080/09654313.2017. 1349079

Ohmer, M. L., Coulton, C., Freedman, D. A., Sobeck, J. L., \& Booth, J. (2019). Measures for Community and Neighborhood Research. SAGE Publications.
Renee, E. Walker, Jason Block, Ichiro Kawachi (2014). The spatial accessibility of fast food restaurants and convenience stores in relation to neighborhood schools. Appl. Spatial Analysis, 7, 169-182. https://doi.org/10.1007/ s12061-013-9095-6

Scannell, L., \& Gifford, R. (2010). Defining place attachment: A tripartite organizing framework. Journal of Environmental Psychology, 30(1), 1-10. https://doi.org/10.1016/j.jenvp. 2009.09.006

Shearmur R. (2010). Scale, distance and embeddedness: Knowledge intensive business services location and growth in Canada, IN: Doloreux, D., Freel, M. and Shearmur, R. (eds.) Knowledge Intensive Business Services: Geography and Innovation, Ashgate, Farnham Surrey and Burlington Vermont.

Silverman, B. W. (1986). Density estimation for Statistics and Data Analysis. Champan and Hall Publishing.

Talen, E. (2000). The problem with community in planning. Journal of Planning Literature, 15(2), 171-183. https:// doi.org/10.1177/08854120022092971

Territorial Agenda of the European Union (2020). Towards an Inclusive, Smart and Sustainable Europe of Diverse Regions. Agreed at the Informal Ministerial Meeting of Ministers responsible for Spatial Planning and Territorial Development on 19th May 2011 Gödöllö, Hungary.

Youssef K. W. F. (2015) Single-access neighbourhoods and neighbourhood cohesion, critical housing analysis, Volume 2, Issue 2, pp. 1-10. https://doi.org/10.13060/ 23362839.2015.3.2.236

Zhu, X., Yu, C.-Y., Lee, C., Lu, Z., \& Manna, G. (2014). A retrospective study on changes in residents' physical activities, social interactions, and neighborhood cohesion after moving to a walkable community. Preventive Medicine, 69(2014), S93-S97. https://doi.org/10.1016/j.ypmed. 2014.08.013

Publisher's Note Springer Nature remains neutral with regard to jurisdictional claims in published maps and institutional affiliations. 